\title{
EXPENSES OF FARM HOUSEHOLDS ON CONSUMER GOODS AND SERVICES IN 2006-2016 IN POLAND
}

Agnieszka Siedlecka ${ }^{1}, \mathrm{PhD}$; Izabela Wielewska ${ }^{2}, \mathrm{PhD}$

${ }^{1}$ Faculty of Economics and Technical Sciences, Pope John Paul II State School of Higher Education in Biala Podlaska, Poland; ${ }^{2}$ Faculty of Agriculture and Biotechnology, UTP University of Science and Technology in Bydgoszcz, Poland

Abstract. The level and structure of household expenses is determined by the amount of income earned. In the analysed period, the results of the household budget survey indicate an increase in both the average monthly disposable income per one person of the household as well as the average monthly expenditure per person on consumer goods and services.

The aim of this paper is to demonstrate how the shift in the level of farm household incomes in relation to households in general influences the change in expenditures on consumer goods and services.

For the purpose of the study, secondary data obtained from the reports of the Central Statistical Office were used.

Key words: household, expenses, quality of life.

JEL code: D1, Q12

\section{Introduction}

The concept of household is defined in a variety of ways. The following groups of definitions can be extracted (Siedlecka, 2015): referring to the family (Piotrowski, 1970, Szczepanski, 1970) of a relevant nature (Hodoly 1971, Syrek, 1980) and of a mixed nature (Kedzior, 1992, Gutkowska, 1997).

The vast majority of definitions of the term household point out to the fact of collecting income and spending it. The level of earned income is the factor that shapes the satisfaction of needs to the greatest extent, and thus affects the quality of life of all household members. The socioeconomic role of household income stems from the following premises: they constitute a measurable factor determining demand and consumption; affect the behaviour of consumption entities earlier than other economic factors; indirectly affect changes of other variables; they are a guarantee of development and social security of economic units (Gasinska, 2016). The main source of household income is from hired work; however, the revenues can also come from agricultural activity, rental or lease of owned property, random winnings, inheritances and donations. There are also non-revenue sources such as benefits. Proper management of the household's finances is associated not only with the accumulation of resources but also with a skilful disposition related to the repayment of previously contracted obligations, planned purchases of consumer goods and services, as well as investment of savings.

This paper attempts to indicate how the shift in the level of farm household incomes in relation to households in general influences the change in expenditures on consumer goods and services. A hypothesis was formulated that farm households have a lower share of expenditure on foodstuffs compared to households in general.

To achieve the assumed goal and verify the hypothesis, analyses were carried out on secondary data obtained from the reports of the Central Statistical Office which were conducted as part of the household budget survey. For the purpose of the study, the selection of households was performed using a representative method which allowed for the generalisation of results. The data from 20072016 were analysed, among others, for farm households. According to the Central Statistical Office Methodology, the farm households are defined as "households, of which the exclusive or main (predominating) source of income comes from the private farm-use in agriculture; an additional source of income for these households may be a retirement pension, disability benefits or other 
non-revenue sources, hired work, self-employment or a freelance labour; this means that the income obtained from additional sources is lower than income obtained from the private farm-use in agriculture" (Household budgets in 2016, p. 15). The following average categories were taken into account: monthly inflows per capita in a household in the form of disposable income, and average monthly outflows per capita in a household in the form of expenses.

\section{Research results and discussion}

The number of households surveyed as part of the budget survey in respective years was at the level of 37.000 entities. The analysed households differed, among others, with respect to the place of residence, the dominant source of income, the number of people in line with the main source of income. One of the features characterising the household was the average number of people per household. In all types of households, a declining trend in the size of households can be observed. Over a ten-year study period, a significant decrease in the average number of people on farms can be noticed.

Farm households are the entities in case of which this decrease is the largest. In 2007, the average number of people per household was 4.33 , while in the households of employed persons it was lower and amounted to 3.44 In 2016, the difference was already lower: the average number of people in the farm households was 3.84, whereas the number of people in the households of employed persons was 3.12. In the analysed period there was also a reduction in the average number of people in the households of retirees and pensioners, this value in 2007 was 2.13 and in 2016 it amounted to 1.89. These variations are to a large extent the result of socio-economic changes taking place in demographic processes. Negative natural population growth, decreasing fertility of women are, among others, the factors conditioning such a distribution of the discussed feature.

The level of disposable income earned on average per capita per month in a household over a ten-year study period developed in a differentiated manner. With regard to the total number of households over the analysed period, an annual increase in the average monthly income per capita in a household could be observed. The scale of year-to-year changes varied. The highest increase took place in 2008 compared to $2007-12.6$ per cent. The lowest increase in 2013 as compared to 2012 amounted to 1.6 per cent. With respect to farm households, the scale of changes was much more diversified - Table 1. 
Changes in the level of the average monthly income per capita in a farm household in 2007-2016

\begin{tabular}{|l|c|c|c|c|c|c|c|c|c|c|}
\hline \multicolumn{1}{|c|}{ Specification } & \multicolumn{7}{c|}{ Years } \\
\cline { 2 - 11 } & $\mathbf{2 0 0 7}$ & $\mathbf{2 0 0 8}$ & $\mathbf{2 0 0 9}$ & $\mathbf{2 0 1 0}$ & $\mathbf{2 0 1 1}$ & $\mathbf{2 0 1 2}$ & $\mathbf{2 0 1 3}$ & $\mathbf{2 0 1 4}$ & $\mathbf{2 0 1 5}$ & $\mathbf{2 0 1 6}$ \\
\hline Available income & & 4.8 & -0.4 & 15.9 & -4.0 & 10.9 & 5.9 & -9.1 & -0.4 & 10.0 \\
\hline $\begin{array}{l}\text { of which disposable } \\
\text { income }\end{array}$ & & 4.4 & 0.0 & 15.5 & -3.2 & 10.5 & 6.9 & -9.7 & -0.3 & 11.0 \\
\hline of which: & & & & & & & & & & \\
\hline $\begin{array}{l}\text { income from hired } \\
\text { work }\end{array}$ & & 13.7 & 13.3 & 0.2 & 6.7 & 15.7 & -4.6 & 14.7 & 2.8 & 5.2 \\
\hline $\begin{array}{l}\text { income from self- } \\
\text { employment }\end{array}$ & & 34.2 & 7.7 & -23.1 & -1.3 & -3.5 & 38.2 & -14.3 & 23.4 & -11.9 \\
\hline $\begin{array}{l}\text { income from } \\
\text { private farm in } \\
\text { agriculture }\end{array}$ & & 3.0 & -2.6 & 21.8 & -7.5 & 11.5 & 7.6 & -14.8 & -1.7 & 5.1 \\
\hline $\begin{array}{l}\text { income from social } \\
\text { security benefits }\end{array}$ & & 7.2 & 3.0 & 2.1 & 13.8 & 5.6 & 6.6 & -3.7 & 2.7 & 2.3 \\
\hline
\end{tabular}

Source: authors' study based on the data obtained from the Central Statistical Office - Household Budgets Surveys in 2007-20016

The accession of Poland to the EU had a significant impact on the income of the rural population, including the income of farm households. It was possible thanks to a greater availability of European Union funds (Utzig, 2016). On the basis of the examined period, with regard to the farm households, both increases in the average monthly income per capita as well as significant decreases occurred. Especially in 2014 compared to 2013 - a decrease of over 9 per cent was noted. Farm households are entities in case of which it is difficult to talk about a stable income situation. Both the level of income from hired labour as well as income from social security benefits is varied. Changes occurring in the income level have a direct impact on the level and structure of consumption. It can be concluded that the basic needs are satisfied in the first place, while the needs of a higher order are satisfied to a greater extent later. This is in line with Engel's law, which says that an increase in income reduces the percentage share of food expenditure in total household consumption expenditure, while the percentage share of spending on durable goods grows (Marciniak, 2004).

An analysis of the linear econometric trend model for household expenses in the scope of expenditure on consumer goods and services allowed to determine the impact of changes in disposable income per capita in a household on the level of expenditures. The analysis was made with respect to changes in income and expenditure in the years 2007-2016.

The estimated function of the model has taken the following form:

$$
Y_{t}=\beta_{0}+\beta_{1} X_{t}+¥_{t}(t=1,2,3, \ldots, 10),
$$

where:

$Y_{t}$ - average monthly expenses per capita in a household,

$\beta_{0}, \beta_{1}$ - structural parameters,

$¥_{\mathrm{t}}$ - random component.

Estimation of the above function of expenses was carried out in total for the whole population as well as for individual groups of households. The results of the estimation of the household expenses regression function are presented in Table 2. 
Results of the estimation of the expenses regression function for individual

Table 2. groups of households

\begin{tabular}{|c|c|c|c|c|c|}
\hline Variable & $\begin{array}{l}\text { Parameter } \\
\text { estimation }\end{array}$ & $\begin{array}{c}\text { Student's } \\
\text { T-Test }\end{array}$ & $\begin{array}{c}\text { Significance } \\
\text { (p) }\end{array}$ & $\begin{array}{c}\text { Shapiro-Wilk } \\
\text { Test }\end{array}$ & $\mathbf{R}^{2}$ \\
\hline \multicolumn{6}{|c|}{ Total } \\
\hline Constant & 290.439 & 7.934 & 0.000 & $0.983 ; p=0.979$ & \multirow[b]{2}{*}{$R^{2}=0.98$} \\
\hline $\begin{array}{l}\text { Variable } \\
\text { (income) }\end{array}$ & 0.585 & 19.790 & 0.000 & $0.939 ; p=0.0542$ & \\
\hline \multicolumn{6}{|c|}{ Of farmers } \\
\hline Constant & 244.588 & 2.931 & 0.019 & $0.896 ; p=0.200$ & \multirow[b]{2}{*}{$R^{2}=0.821$} \\
\hline $\begin{array}{l}\text { Variable } \\
\text { (income) }\end{array}$ & 0.497 & 6.059 & 0.000 & $0.926 ; p=0.413$ & \\
\hline \multicolumn{6}{|c|}{ Of employees } \\
\hline Constant & 281.674 & 8.580 & 0.000 & $0.980 ; p=0.967$ & \multirow[b]{2}{*}{$R^{2}=0.984$} \\
\hline $\begin{array}{l}\text { Variable } \\
\text { (income) }\end{array}$ & 0.578 & 21.933 & 0.000 & $0.936 ; p=0.508$ & \\
\hline \multicolumn{6}{|c|}{ Self-employed } \\
\hline Constant & 659.257 & 8.376 & 0.000 & $0.893 ; p=0.184$ & \multirow[b]{2}{*}{$R^{2}=0.874$} \\
\hline $\begin{array}{l}\text { Variable } \\
\text { (income) }\end{array}$ & 0.382 & 7.433 & 0.000 & $0.984 ; p=0.985$ & \\
\hline \multicolumn{6}{|c|}{ Of retirees and pensioners } \\
\hline Constant & 265.071 & 7.224 & 0.000 & $0.954 ; p=0.718$ & $R^{2}=0.984$ \\
\hline $\begin{array}{l}\text { Variable } \\
\text { (income) }\end{array}$ & 0.650 & 22.237 & 0.000 & $0.977 ; p=0.949$ & \\
\hline
\end{tabular}

Source: authors' study based on the data obtained from the Central Statistical Office - Household Budgets Surveys in 2007-20016

Estimation of $\beta_{1}$ parameter indicates that an increase in the total disposable income of households by PLN 1 per person will result in an increase in spending on consumer goods and services in total by PLN 0.585 per person on average. Regression function explains the development of total expenditure in 98 per cent $(R 2=0.98)$. A high coefficient of determination (R2) indicates a high model fit. This fact is also confirmed by the coefficient of variation ( $V$ ) at the level of 9.11 per cent constant and 13.37 per cent to the variable. The normality test of the distribution carried out with the Shapiro-Wilk Test points to a normal distribution at the significance level of 0.05 - for all groups of households (Table 1 ).

With regard to households where the main source of income comes from a private farm, the $\beta 1$ parameter indicates that the increase in disposable income per capita per farm by PLN 1 will result in an increase in expenditure on consumer goods and services on farm households by PLN 0.497 per person on average. The change was lower only with respect to households gaining income from self-employment. The parameter $\beta 1$ for this group of entities shows that the increase in disposable income per person per farm by PLN 1 will increase the expenditure on consumer goods and services on farm households by PLN 0.382 per person on average. Definitely the largest changes occur in households of retirees and pensioners. Change in disposable income by PLN 1 increases the expenditure on consumer goods and services in these households by PLN 0.650.

Expenses on consumer goods and services, which were incurred over a ten-year study period, accounted for about 95 per cent of household expenditures in general. With regard to farm households, in the years 2009, 2011, 2013. 2014-2016, these expenses amounted to 96 per cent. The last three years have noted a successive increase amounting to 96.5 per cent in 2016 . When analysing particular categories of expenses, it should be noted that the highest share of 
expenditure is definitely in the category of food and non-alcoholic beverages. A similar situation takes place in other EU countries, i.e., Latvia, where food expenditure is a key element in the household expenditure budget (Upite I. et al., 2014). The general structure of households' expenditure in Central and Eastern European Countries (the Czech Republic, Lithuania, Latvia, Poland and Slovakia) indicates a lower standard of living compared to EU-15 countries. These countries strive to bridge the differences in the level of consumption structure that takes place over the years (Mikula, 2017).

Over the years, their share in the expenditure of consumer goods and services has changed slightly, but these were minor changes both in terms of households in general, and in terms of farm households.

It should be noted that in the case of farm households, food and non-alcoholic beverages represent a much larger share of expenditures as compared to the expenditures of households in general. Such a high share is related to the fact that the average monthly disposable income per capita in a household in this group of entities is the lowest. In 2007, it amounted to PLN 846.76 in farm households, and was even lower than the income in households of pensioners (PLN 937.63). The situation has not changed over the ten-year study period. The level of income in farm households was lower compared to other groups of households. In respective years, this difference ranged from 9 to 22 per cent compared to the income of all households.

The second category of expenses, i.e., in terms of the amount of expenditures, relates to the use of housing and energy carriers. During the analysed period, these expenses constituted from 18.4 per cent of household expenditures on consumer goods and services in 2007 to 20.8 per cent in 2013 (the highest share). In the case of farm households, this figure was lower and amounted to 14.9 per cent in 2007 and 18. per cent in 2013 (the highest share). This may be related to the fact that farms are situated in rural areas, where the vast majority of inhabitants live in their own homes, which is connected with the lack of expenses incurred on, e.g., rent.

Another aspect that should not be underestimated is the shift in expenditure on particular groups of expenses stemming from the change in the level of disposable income.

The results of the estimation of the expenditure model indicated that from each additional PLN 100 earned per capita, the amount of PLN 58.50 per person in households in general, and the amount of PLN 49.70 per person in farm households will be used for consumption of goods and services. Amongst particular product groups, food and non-alcoholic beverages are definitely dominant. An increase in income by PLN 100 will increase expenses on food and non-alcoholic beverages by PLN 18.90 by person in households in general, and by PLN 10 per person in the farm households.

Health expenses constitute another category of farm household expenditures in case of consumer goods and services. An increase in income by PLN 100 will affect expenditure increase by PLN 6.30 and by PLN 3.80 per capita in households in general and in farm households respectively.

In 2004-2015, the incomes of the rural population increased in nominal terms by 101.5 per cent. Despite the fact that the increase is more than 15 per cent higher in comparison to the average inhabitant of the city, income disparity between rural residents is significant. As a result, it affects the structure of spending on consumer goods and services. On average, farm households spend less on services in the field of education, health and tourism compared to other groups of households. 
Results of the estimation of the expenditure model for selected assortment groups for households in 2007-2016

\begin{tabular}{|c|c|c|c|c|}
\hline \multirow[b]{2}{*}{ Assortment group } & \multicolumn{2}{|c|}{ Households in general } & \multicolumn{2}{|c|}{ Farm households } \\
\hline & Model & $\begin{array}{c}\text { Theoretical change in } \\
\text { the level of expenses } \\
\text { while increasing } \\
\text { income by PLN } 100\end{array}$ & Model & $\begin{array}{c}\text { Theoretical change in } \\
\text { the level of expenses } \\
\text { while increasing } \\
\text { income by PLN } 100\end{array}$ \\
\hline $\begin{array}{l}\text { Food and non- } \\
\text { alcoholic beverages }\end{array}$ & $\begin{array}{l}Y_{t}=57.839+ \\
0.189 t \\
R^{2}=0.753 \\
p=0.001\end{array}$ & PLN 18.90 & $\begin{array}{l}Y_{t}=139.305+ \\
0.100 t \\
R^{2}=0.787 \\
p=0.000\end{array}$ & PLN 10.00 \\
\hline $\begin{array}{l}\text { Clothing and } \\
\text { footwear }\end{array}$ & $\begin{array}{l}Y_{t}=6.890+ \\
0.046 t \\
R^{2}=0.779 \\
p=0,001\end{array}$ & PLN 4.60 & $\begin{array}{l}Y_{t}=18.396+ \\
0.023 t \\
R^{2}=0.452 \\
p=0.033\end{array}$ & PLN 2.30 \\
\hline $\begin{array}{l}\text { Furnishing, } \\
\text { household } \\
\text { equipment and } \\
\text { routine }\end{array}$ & $\begin{array}{l}Y_{t}=21.351+ \\
0.029 t \\
R^{2}=0.685 \\
p=0.003\end{array}$ & PLN 2.90 & $\begin{array}{l}Y_{t}=26.969+ \\
0.013 t \\
R^{2}=0.475 \\
p=0.027\end{array}$ & PLN 1.30 \\
\hline Health & $\begin{array}{l}Y_{t}=-12.364+ \\
0.063 t \\
R^{2}=0.948 \\
p=0.000\end{array}$ & PLN 6.30 & $\begin{array}{l}Y_{t}=-8.424+ \\
0.038 t \\
R^{2}=0.739 \\
p=0.001\end{array}$ & PLN 3.80 \\
\hline Transport & $\begin{array}{l}Y_{t}=24.683+ \\
0.070 *\end{array}$ & & $\begin{array}{l}Y_{t}=18.213+ \\
0.061 t \\
R^{2}=0.615 \\
p=0,007\end{array}$ & PLN 6.10 \\
\hline Communication & $\begin{array}{l}Y_{t}=-4.194+ \\
0.051^{*}\end{array}$ & & $\begin{array}{l}Y_{t}=5.589+ \\
0.029 t \\
R^{2}=0.753 \\
p=0.001\end{array}$ & PLN 2.90 \\
\hline
\end{tabular}

\section{Conclusion}

1) The level of average monthly disposable income per one person in a household has a significant impact on the average monthly level of expenditure on consumer goods and services. This varies in particular types of households. In case of farm households, the category generating the highest expenditure is the assortment group of food and non-alcoholic beverages.

2) An increase in the average monthly disposable income per person influences the increase in expenditures in particular assortment groups. However, the highest increase is in the category of food and non-alcoholic beverages.

3) The second assortment group in terms of the increase in the average monthly level of expenditure in farm households is the transport category (including both expenses related to own means of transport and their operation as well as payments for journeys and transportation costs).

4) The structure of spending on consumer goods and services in Poland is similar to other Central and Eastern European Countries.

5) It is advisable to continue to observe the changes in the structure of income and expenditure of farm households in order to make an attempt to determine their level of living. 


\section{Bibliography}

1. Gasinska, M. (2016). Dochody gospodarstw domowych w Polsce - wybrane obiektywne i subiektywne ujecia i dane (Household incomes in Poland - selected objective and subjective approaches and data), ZNUV, 50(5), p. 101.

2. Gutkowska, K. (1997). Rodzinne gospodarstwa domowe na wsi w warunkach gospodarki rynkowej (Family households in the countryside under market economy conditions). Wydawnictwo SGGW, Warszawa, pp. 1920.

3. Hodoly, A. (1971). Gospodarstwo domowe i jego rola społeczno-ekonomiczna (Household and its socioeconomic role). Wydawnictwo KiW, Warszawa, p. 12.

4. Household budgets in 2006, Central Statistical Office, Warsaw 2007.

5. Household budgets in 2007, Central Statistical Office, Warsaw 2008.

6. Household budgets in 2008, Central Statistical Office, Warsaw 2009.

7. Household budgets in 2009, Central Statistical Office, Warsaw 2010.

8. Household budgets in 2010, Central Statistical Office, Warsaw 2011.

9. Household budgets in 2011, Central Statistical Office, Warsaw 2012.

10. Household budgets in 2012, Central Statistical Office, Warsaw 2013.

11. Household budgets in 2013, Central Statistical Office, Warsaw 2014.

12. Household budgets in 2014, Central Statistical Office, Warsaw 2015.

13. Household budgets in 2015, Central Statistical Office, Warsaw 2016.

14. Household budgets in 2016, Central Statistical Office, Warsaw 2017, p. 15

15. Kedzior, Z. (1992). Gospodarstwo domowe - podmiot gospodarujący (Household - business entity). Wydawnictwo Instytutu Rynku Wewnetrznego i Konsumpcji, Warszawa, pp. 3-4.

16. Marciniak, S. (Ed.) 2004. Makro- i mikroekonomia. Podstawowe problemy wspołczesnosci (Macro and microeconomics. Basic problems of contemporary Times). Wydawnictwo Naukowe PWN, p. 200.

17. Mikula, A. (2017). Changes in the structure of households' consumption expenditures in selected countries of the European Union, Economic Science for Rural Development, No. 46, p. 211.

18. Piotrowski, J. (1970). Wspołczesne gospodarstwo domowe i jego funkcjonowanie [w:] Ekonomicznospołeczna rola gospodarstwa domowego (Contemporary Household and its Functioning. In The socioeconomic role of a household). Wydawnictwo CRZZ, Warszawa, p. 76.

19. Siedlecka, A. (2015). Srodowiskowe aspekty funkcjonowania wiejskich gospodarstw domowych na obszarach przyrodniczo cennych wojewodztwa lubelskiego (Environmental Aspects of the Functioning of Rural Households in Naturally Valuable Areas of the Lubelskie Province). Wydawnictwo PSW JPII, Biala Podlaska, p. 28.

20.Syrek, M. (1980). Ekonomiczne funkcje wspolczesnego gospodarstwa domowego (The economic functions of a modern household). Wydawnictwo Uniwersytetu Slaskiego, Katowice, p. 25.

21.Szczepanski, J. (1970). Elementarne pojecia socjologii (Elementary Concepts of Sociology). Wydawnictwo PWN, Warszawa, p. 300.

22. Upite, I., Pilvere, I., Nipers, A., Krievina, A. (2014). Loyalty of consumers to food in Latvia, Economic Science for Rural Development, No. 35, p. 62.

23. Utzig, M. (2016), Struktura wydatkow konsumpcyjnych ludnosci wiejskiej i miejskiej w Polsce (The structure of consumer expenditure of rural and urban population in Poland), Handel wewnetrzny, 1(360), p. 161 